\title{
Rape as an Element of Power Dominance in Nampally Road by Meena Alexander and Homegoing by Yaa Gyasi
}

Maharajalakshmi.S

M.A.English

Department of English

Sadakathullah Appa College

Tirunelveli, Tamil Nadu, India

mahalakshmisns1993@gmail.com

Dr.P.Abukaniba Meeran

Assistant Professor

Department of English

Sadakathullah Appa College

Tirunelveli, Tamil Nadu, India

abukanibameeran@gmail.com

DOI: https://doi.org/10.24113/ijellh.v9i4.10982

Abstract

In the subaltern countries such as India and Africa, the form of government adapted or infused was that of the Colonial or European form of governance. For instance, during the colonial invasions in India and Africa the governance was changed or forced from the feudal system to the constitutional form of government. While the colonial form of governance has many positive aspects, the inhumane practice of rape was prominent to exhibit political dominance. In order to prove this practice of inhumane act two novels have been chosen for this research. One is Nampally Road by Meena Alexander that talks about the societal 
imbalance caused during the period of "Emergency act" and the other is Homegoing by Yaa Gyasi that deals with a period of three centuries starting from the "Slave Fugitive act" to post independence, where the plots depict the prominence of rape to exhibit power and control the natives.

Keywords: Rape, Colonialism, Dominance.

Rape, unlawful sexual activity, most often involving sexual intercourse, against the will of the victim through force or the threat of force or with an individual who is incapable of giving legal consent because of minor status, mental illness, mental deficiency, intoxication, unconsciousness, or deception which is defined by the Britannica Encylopedia. In many jurisdictions, the crime of rape has been subsumed under that of sexual assault. Rape was long considered to be caused by unbridled sexual desire, but it is now understood as a pathological assertion of power over a victim. Rape is often explained as a manifestation of racial, ethnic, and

"Her sari was stiff with blood. I could tell by looking. She lay curled up on the mud floor of the cell just behind the wooden desk. Her face was held up by the mud. In spite of the mosquitoes buzzing over her, both eyes were open. She was breathing in jagged, irregular breaths.” ( Nampally Road 57)

class hatred or as stemming from a patriarchal system in which women are viewed as the property of men. Whatever its origins, rape is a serious crime and is treated as a felony in most countries with common-law systems. In many rape trials, the guilt of innocence of the accused hinges on whether or not the victim consented to sexual intercourse. The determination of consent often can lead to distressing cross-examinations of rape victims in court. (https://www.britannica.com/topic/rape-crime)

"Now Rameeza's story spread through Hyderabad like smoke from the burning police station. A young woman had come in from the mountains with her 
husband. They had gone to see the celebrated Isak Katha at Sagar Talkies. It was late at night. Walking back to the home of relatives, along the deserted road in Gowliguda, they fell prey to a horde of drunken policemen. Rameeza was gang raped. Her husband had his brains beaten out. His body recovered from a well behind the police station. Swollen, the eyes puffed out, it was identified by his brother, a lorry driver in Hyderabad. Now the police station was burning, iron bars and all, a quick, sudden revenge. (Nampally Road 58).

The first novel to be discussed in this research is Nampally Road by Meena Alexander that talks about the protagonist Mira Kannadical, who is in search of her identity. Mira comes from London after finishing her post graduation in English Literature and works at the Central University of Hyderabad. In the novel she is struggling to find her true identity like whether she wants to serve herself for the society. We find that she questions her purpose in life when she meets Rameeza Be. Rameeza Be is a victim of rape in Hyderabad. This inhumane act was carried by the very own protectors of the country, the police men. The police men happen to known as the "Ever Ready Men" who work for the Chief Minister of Hyderabad, Limca Gowda. The Chief Minister is portrayed in a negative light in the novel, and is seen as a character who uses his power to suit the needs of him and his associates.

"I knelt by her and saw that her eyes were cooler now but maintained that terrible darkness. She would not speak to us. I think she could not speak to us. She made little whispers and short cries as if she had come from another country and the words we spoke, or even our manner of making them, the physicality of sounds that passed though our lips, meant little to her. Sometimes she pointed to her thin belly covered over with the old red cloth, sometimes to her back, which was badly bruised." (Nampally Road 79) 
The responsibility of the police department is to serve and protect the people. They have the responsibility of maintaining peace and calm in the society but instead they misuse power and use the privilege of their job to satisfy the needs of the political leaders who reward them with money. This attitude of such officials makes the citizens of Hyderabad lose trust and hope on "the supposed to be protectors of the locality- The Police Department". In the fiction the event of rape is exposed only in the sixth of the ten chapter of the novella, and it is from this chapter the actual rising action of the plot takes place. This incident where the life of Rameeza is put into question, is where the protagonist Mira realizes her purpose in life that is to serve the people who have become voiceless like Rameeza. Rameeza is seen living a contended life with her husband and one should not blame her beauty as the cause and eligibility for rape. Rape is used an instrument to enact dominance of power upon the ordinary powerless citizens of the society so that they are kept in constant fear. The plot of the novel takes place during the time of the "Emergency Act". In the time of the act's implement freedom of speech or expression through any medium was completely curtailed and the information that were published were altered to suit or favor the ruling government.

"Her body was like a lovely tree, a guava with its pale skin, filled with angry wounds. A small shake, a twitch, a whisper, a cry that came out of her throat, that was all.” ( Nampally Road 80)

The act of rape committed like thugs by the police has created a sense of rebellion and fear among the people of the society. The amount of fear was more than the rebellion because the people were concerned about the safety of the women of their family. They feared that "such" incident would bring dishonor to the name earned by their family. This trick of the powerful where police perform an inhumane act of rape, is seen as act of protection and diversion from people raising their voices against the ruling government. 
"Your mother was once a slave for a Fante family. She was raped by her master because he too was a Big Man and big men can do what they please, lest they appear weak, eh?” ( Homegoing 38)

In the second novel taken for research is Homegoing by Yaa Gyasi. Effia and Esi are two sisters with two very different destinities. One sold into slavery; one a slave trader's wife. The consequences of their fates reverberate through the generations that follow. Taking us from the Gold Coast of Africa to a cotton-picking plantation in Mississippi, from a village missionary school to the dive bars of Harlem, spanning three continents and seven generations, the plot depicts the domination of the Colonial regime and also the Federal government upon the natives of Africa.

"One of them grabbed a woman on the far end and pushed her against the wall. His hand found her breasts and he began to move down the length of her body, lower and lower still, until the sound that escaped her lips was a scream." ( Homegoing 47)

In this novel the act of rape is seen as an act of disgrace to the clan the women belong to. For instance an Asante woman is captured as a slave by a Fante. Warrior is seen raping a woman to bring dishonor to her and the clan. Even the colonizers capture the native women as slaves and keep them in the dungeons in the British Palace in the Gold Coast of Africa. The men who drink palm wine come to the dungeon with their faces flushed, grab a woman of their and assault her and later push her to the ground. They are left mostly left half or completely naked as they would come again and perform the inhumane act.

"He put her on a folded trap, spread her legs, and entered her. She screamed, but he placed his hand over her lips, then put his fingers in her mouth. Biting them only seemed to please him, and so she stopped.” ( Homegoing 48) 
Esi is born as the daughter to the King of a native tribe but since she is brought as a slave by the European Colonizers she is subjected to be a victim of rape. The ruling or dominating men do not understand nor care about the emotional turmoil that women undergo caused by this physical torture. The act of rape is seen as an act of pride and as a way of exhibiting dominance over the natives of the country. The wife, daughter or the women who belong to the family of the native tribe leader is captured and is assaulted to bring shame and dishonor to them. This act is done to implement racism through generations. In the fiction after several generations, we find that immigrant African couple, who are separated due to differences are forced to perform sexual act by the Americans. This forced act is a reminder to the immigrants by the natives of the western countries that they would not be accepted and treated as equal even if they adopt the western culture and traditions.

"She your woman? he asked. .... Well, why don't you come over here and give her a kiss? the grey suit asked... And he kept his word. Robert did all the work that night while the blue suit guarded the door. It wasn't more than a few tear-stained kisses and carefully hands. Before the gray suit could ask for Robert to enter her, he came, a shuddering, breathy thing. Then, immediately after, he grew bored with his game.’(Homegoing 215)

There is another incident of rape which takes place in the latter half of the fiction. Robert who is a white man married a native African woman Willie Black and they moved to New York, with the aim of a sophisticated life. The situations do not favor them and so the couple went in separate ways so that Robert went to pursue opportunities he got as he was a white man. He earned much more in a month than what Willie could earn in a year as she could not pursue any stable job as she was seen unfit because she was an immigrant. The icing on her fate was the forced sex by Robert as he directed by his white friends as they found out the crime of them being formerly married to each other. 
The two novels considered for this research article are taken from Indian and African Diasporic where the time period of the former happens during the 1960' and the latter travels from 1770 to the previous decade. Irrespective of the time period, the inhumane act of rape is carried out to depict power. In Nampally Road, the police are seen raping a married women Rameeza Be, who went came with her husband to watch the movies. The police claim her beauty as the reason for rape. In Homegoing, we see two incidents of rape, where one is seen enacted upon Esi by the Colonial invaders to suppress the power of the native tribe leaders and a forced sexual act by Robert who is a white man upon his former immigrant wife Willie Black as an act of reminding the immigrant people that they are not welcome to the western land. This inhumane practice of rape is predominantly seen in these countries that took up colonized form of culture or governance. Every culture has its pros and cons but no culture should inculcate or promote the practice of rape for any motive especially to suppress the people. 


\section{Works Cited}

Alexander, Meena, Nampally Road. San Francisco, USA, Mercury House. 1991.

Gyasi,Yaa, Homegoing. USA, Viking- Penguin Random House, 2016.

Falola, Toyin, The Power of African Culutres. New York, The University of Rochester Press, 2003.

Mishra, Vijay, The Lierature of the Indian Diaspora: Theorizing the Diasporic Imaginary. NewYork, Routledge, 2007.

https://www.britannica.com/topic/rape-crime 